\title{
Empirical Analysis of Relation Between Export Trade and Economic Growth in Henan Province
}

\author{
Xiangfen Wang \\ ZhengZhou University for Science and Technology, ZhengZhou, 450000, China
}

Keywords: Export trade, GDP, Empirical Research

\begin{abstract}
With the pace of economic globalization accelerated, the contribution of exports to economic growth is increasing. In this paper, 2000--2014 years Henan GDP and exports sample data, correlation analysis and regression analysis, the relationship between the local GDP growth in export trade in Henan empirical research, Henan proposal to promote the rapid and healthy development of export trade on the basis of the Suggestions.
\end{abstract}

\section{Introduction}

In 2000, Henan GDP was 505.299 billion yuan, the export volume was 12.365 billion yuan (calculated as the annual average exchange rate of the RMB against the US dollar central parity basis). 2014, Henan GDP reached 3.49 trillion yuan, the export trade amounted to 241.88 billion yuan. Fifteen years, GDP grew nearly six-fold, exports increased by 18 -fold. As export growth "troika" in the end, one can have much role in promoting economic development in Henan Province, is the focus of this paper to explore the issue. In this paper, fifteen years Henan GDP and exports data related to the problem analysis and regression analysis, expecting to find the inherent long-term equilibrium relationship between the two, for export to Henan to play a greater role in promoting economic growth, put forward the corresponding countermeasures.

\section{General situation of economic development in Henan}

Since the reform and opening up from 1978, Henan's economy gradually transformed from agricultural production into a modern industry and modern service industries. 30 years, Henan is the country's economic development has made important contributions. 2012, Central Plains Economic Zone Planning officially rose to national macroeconomic development strategies as one of the important Central Plains Economic Zone in Henan province will usher in another spring in the history of its development.

\section{Industrial structure of Henan}

Industrial structure determines the quality and speed of a local economic development. Over the years, Henan is the country's major grain production bases, major grain producing areas, Henan charged with the important mission of the national urban food supply. Therefore, agriculture has always occupied an important position in the industry. After 2000, Henan industrial structure has been optimized and certain adjustments, Henan grain planting proportion has declined, the proportion of livestock increased. The second industry, light industry output value rising, has become another engine of economic growth in Henan. In recent years, Henan tertiary industry has been rapid development, such as the emerging electronic business development particularly prominent in 2015 double 11, Taobao Henan amounted to 3.4 billion yuan the day of the transaction, the transaction amount ranked ninth, these data Henan has once again proven the rising economic strength.

\section{Henan's GDP}

GDP is one of the most important indicator of the macroeconomic situation of a region, China's reform and opening up in 1978, when GDP Henan less than 17 billion yuan of the total, in 1991 GDP Henan RMB 100 mark for the first time, after entering Henan fast-track economic development, Henan GDP in 2000 up to 505.299 billion yuan, after a lapse of five years, Henan GDP stepped into one trillion yuan in 2014, Henan GDP of up to 3.49 trillion yuan. After 2000, Henan's GDP growth 
rate remained at above $10 \%$. Since 2007, total economic output in Henan remained fifth in the country.

\section{Export status and existing problems of Henan export}

\section{Henan's export status}

The beginning of reform and opening up in 1978, Henan annual exports less than $\$ 5$ million, Henan's exports weak economic foundation, but rapid development, in 2014 in Henan foreign trade exports up $\$ 39,383,700,000$. Henan has maintained a trade surplus, foreign trade and exports both rapid growth, 2002--2004 years Yes exports after China joined the WTO in Henan ushered in the first period of rapid growth, 2010 - The economic crisis after 2013 was ushered in Henan export first Two high-speed growth period, during which the average export growth rate of Henan more than $50 \%$, far above the national average over the same period, ranking first of the six central provinces. Henan export scale has expanded each year, while exports of species, nature structure, export units, trade, target markets are constantly changing. Exports gradually to change the direction of semi-finished products from raw materials and other primary products, mainly state-owned export-oriented units initially, and now it is private enterprises, private enterprises and state-owned enterprises of the three pillars, and common development. Export trade of traditional goods exports from the past to the present development of processing trade. Henan export companies are constantly open up new markets, the level of merchandise exports are escalating. Henan export trade in order to promote local economic development and solve the employment problem of labor plays an important role.

\section{Problems existing in Henan's export}

Although these exports in Henan has made remarkable achievements, but compared with other provinces, there are still many problems.

\section{Low technical content of export commodities}

For a long time, Henan are export-oriented resource-based commodities, other non-ferrous metal exports throughout Henan list of export commodities, steel, lead, aluminum, copper, nearly 10 often topped the list, accounting for the export of such basic materials Henan commodity exports to more than three percent of these products basically no technical content, in the international market is not much of a competitive advantage. Although the proportion of exports of electromechanical products in Henan large, but high-tech, high value-added goods less and less, far less than in Jiangsu and Zhejiang and other coastal cities when export levels. Henan relatively small number of high-tech export enterprises, resulting in generally low level of exports, lack of technical content.

Weak industrial competitiveness of export commodities

Henan has always been the country's major grain production base, has been the traditional advantages of agricultural export commodities in Henan, but as an industrial raw material industry is located in the bottom of the hierarchy, but also combined with Henan local agricultural products processing technology is weak, the international market of agricultural products face green trade barriers sleepy, a considerable part of agricultural exports difficult to compliance, the export volume of agricultural products decreased year by year. Henan is the country's well-known chemical industry base, chemical products are high energy consumption, high pollution and low output, low income, are the focus of Customs seized products, so exports to redress. Future development of the world economy is a high-tech industry, but exports of high-tech products in Henan weak, relatively slow pace of development of high-tech industries, export of finished products are mostly labor-intensive low value-added products, not high-tech.

Foreign trade market is too concentrated, there is a certain risk

At present, Henan's exports is the EU's largest trading partner, followed by the United States, Hong Kong, South Korea. 2013, Chinese exports to the product of the total amount of more than one country for more than $60 \%$ of exports, while the major export products like Henan human hair products are mainly exported to the United States and South Korea, according to statistics, South Korea's annual exports to account for such human hair products more than 40 percent of products, the export market is too concentrated, it will only lead to export enterprises to increase the economic and political risks. 
A serious lack of foreign trade professionals

There is a limited number of foreign trade enterprises in Henan Province, a considerable part of small-scale foreign trade enterprises, these export enterprises in small and micro enterprises to introduce talent, training is not enough emphasis on the importance unaware of professionals, resulting in some loss of foreign talent. For state-owned foreign trade enterprises nature, due to problems of employment mechanism, limiting outstanding foreign talent to enter, and ultimately lead to the loss of foreign talent. Currently, the Henan line of foreign trade and management personnel is quite lacking, according to the survey, Zhengzhou, with exports amounting to about \$20 million business, the lack of $80 \%$ of the companies only three to five professionals in foreign trade, foreign professionals have been severely constrained enterprise business to carry out foreign trade development and nurturing of talent has become a serious problem in Henan export enterprises must face and to focus on resolving.

\section{Econometric analysis of Henan's export trade to economic growth}

\section{Correlation analysis of Henan's GDP and annual export amout}

2000--2014 average annual GDP growth rate was 19.02\% in Henan, the average annual growth rate of total exports was 22.64 percent. To reduce calculation errors and eliminate heteroscedasticity time series, special and annual exports to GDP (P) be the natural logarithm transformation process. Generated in EXCEL lnGDP and lnP scatterplot, seen from the scatter plot, was a significant positive correlation between GDP and export volume of Henan. Let annual exports of x, GDP is y, further calculating the correlation coefficient $r=0.56$, explain the degree of correlation of export and GDP in general.

\section{Regression analysis}

For 2000--2014 Henan GDP and exports (P) of the natural logarithm, use OLS to estimate the model parameters, the use of Eviews 3.0 software for its regression process, results are as follows:

\begin{tabular}{|c|c|c|c|c|}
\hline \multicolumn{5}{|c|}{ „NGDP = $3.896754283+0.9410263758 * L N P$} \\
\hline \multicolumn{5}{|c|}{ Dependent Variable: LNGDP } \\
\hline \multicolumn{5}{|c|}{ Method: Least Squares } \\
\hline \multicolumn{5}{|c|}{ Date: 06/06/15 Time: 14:32 } \\
\hline \multicolumn{5}{|c|}{ Sample: 20002014} \\
\hline \multicolumn{5}{|c|}{ Included observations: 15} \\
\hline Variable & Coefficient & Std. Error & t-Statistic & Prob. \\
\hline $\mathrm{C}$ & 3.896754 & 0.283154 & 12.77905 & 0.0000 \\
\hline LNP & 0.941026 & 0.053111 & 15.74328 & 0.0000 \\
\hline R-squared & 0.934950 & \multicolumn{2}{|c|}{ Mean dependent var } & 8.608531 \\
\hline Adjusted R-squared & 0.931698 & \multicolumn{2}{|c|}{ S.D. dependent var } & 0.999065 \\
\hline S.E. of regression & 0.261102 & \multicolumn{2}{|c|}{ Akaike infocriterion } & 0.238699 \\
\hline Sum squared resid & 1.363488 & \multicolumn{2}{|c|}{ Schwarz criterion } & 0.337885 \\
\hline Log likelihood & -0.625687 & \multicolumn{2}{|c|}{ F-statistic } & 287.4577 \\
\hline Durbin-Watson stat & 0.702149 & \multicolumn{2}{|c|}{ Prob(F-statistic) } & 0.000000 \\
\hline
\end{tabular}

These estimates result coefficient of determination was 0.941026 , which fully shows that the model fits well on the whole. About coefficient significance test, for ß2, t statistic of 15.74328. Given $\mathrm{a}=0.05$, check $\mathrm{t}$ distribution table, in degrees of freedom $\mathrm{n}-2=$ under 13 conditions to obtain the critical value of 3.567, t statistic is much larger than the critical value, the impact of trade on GDP of Henan export more significant. From a theoretical perspective, LNGDP $=3.896754283+$ $0.9410263758 *$ LNP, if the formula described in Henan exports increased by 1 million, then the GDP would mean an increase of about 0.94 yuan.

\section{Conclusions and suggestions}

Through the above empirical research, the following conclusions:

a). For a long term view, Henan export trade showed a rising trend, but the contribution of exports to economic growth in Henan's far below the national average, and the Yangtze River Delta, Pearl 
River Delta, the gap is even greater coastal cities, illustrate this point strong economic development in Henan genus typical introverted mode.

b). Henan exports on economic growth is clearly insufficient pulling power, reflects the current export Henan there are many problems.

To maximize the export trade of Henan pulling power of economic growth, promote the healthy and stable and rapid development of Henan export trade, especially the following recommendations for government departments and export enterprise reference.

1). In order to build Zhengzhou Airport Economic comprehensive experimental zone as the basis, vigorously promote the development of small and medium export enterprises.

With the investment of Zhengzhou Airport Economic comprehensive experimental zone construction and use, Zhengzhou future will become an important gateway to inland areas of opening up, Henan foreign trade import and export business is also about to enter the phase of great development by leaps and bounds. Henan Fengshen tire like the current number of such export enterprises above designated size is very limited, small and medium export enterprises accounted for 95\%, while small and medium export enterprises often face poor market channel construction, financing and credit guarantee common problems and difficulties, these problems often as a constraint to the development of small and medium export enterprises stumbling block. How to effectively play small and medium export enterprises in Henan economy pulling power, which undoubtedly need the support of relevant government departments. For example, the government regularly hosted international trade fairs in different sectors, the government has commissioned local financial institutions to give small and medium enterprise financing export deals and provide a credit guarantee. Export outlet for small and medium enterprises to open a green channel, simplifying the cumbersome export procedures, improve customs clearance efficiency.

2). The construction of the Central Plains Economic Zone as an opportunity to actively cultivate export advantage of local agricultural products

Henan is a is the major grain, cotton, oil production base. Qixian garlic, mushroom xiayi Xichuan pepper, Yanling seedlings, faith Tippy, Xinzheng jujube and other local specialty products in the international markets have a strong competitive edge, in the background of the Central Plains Economic Zone, Henan should take advantage of the natural geographical environment Advantages to develop specialized agriculture. Future, Henan should develop characteristic earned a prominent position on the important agriculture, government focus on supporting those characteristics of agricultural products with international competitive advantage, create brand characteristics of agricultural products, increase the characteristics of agricultural promotion and international marketing efforts, improve the characteristics of agricultural products level of deep processing, extend its industrial chain, form the characteristic advantages of the main producing areas of agricultural products, improve the competitiveness of agricultural products, and then expand exports of agricultural products.

3). Hold the baton to undertake domestic industrial transfer, develop processing trade

In 2010, the southeast coastal city of processing trade enterprises have begun to gradually shift to the mainland, especially in such populous transferred to Henan, as Foxconn, Gree and other large-scale processing enterprises to join, Henan processing trade into the fast lane. Henan should make full use of this opportunity, to complete the transformation and upgrading of processing trade, processing trade tradition lowest income belongs to the entire product chain link. Current and future period of time, Henan should Processing Trade and the Central Plains Economic Zone development strategy combining resources industry gathering area integration advantages, to take a new road to contemporary processing trade, rely on high-tech driven industrial transformation and upgrading of processing trade, increase product added to further enhance the processing trade in the international market competitiveness, expand the international market scope of processing trade.

4). While the development of commodity export trade, emphasis on the development of trade in services

With the great development of the international economy, the services industry in the national economy increasing proportion of service trade import and export trade in an increasingly showing its 
important role. Henan is concerned, has been driven by import and export trade is trade in services (insurance, transportation, etc.) development. Service trade export capacity seriously inadequate. After 2000, Henan's traditional strengths of the service sector - tourism has been some development, but the pace of development compared to other provinces or slow a length. Henan is rich in tourism resources, such as the Shaolin Temple, the Longmen Grottoes these tourist attractions in the country and the world are very famous, Henan should further regulate the tourism services market, increase development efforts related services such as transportation, food and beverage, hotel services, and promote tourism Export. In addition, Henan human resources is also very rich, so there are obvious advantages in terms of labor export. Labor export is not a simple labor output, in order to play a greater labor export advantage, Henan should pay attention to training workers professional skills, improve their overall competitiveness international market.

5). Increase the training of professionals in foreign trade, create excellent foreign trade personnel

In recent years, Henan tier foreign talent and foreign trade management personnel is very scarce. Foreign staff mobility is too large, mostly from Henan flow to the coastal cities, comprehensive high-quality, rich experience in the international market is difficult to settle foreign trade personnel, the lack of human capital and instability has seriously hampered the development of export enterprises in Henan Province. Therefore, the proposed Henan spared no expense on the one hand to attract foreign outstanding foreign talent to Henan development. On the other hand will have to attach importance to training local Applied foreign talent, and take school-enterprise cooperation or training mode counterpart road, allow enterprises to participate in the training process earlier trade professionals, students so trained to better meet the business real needs.

6). The implementation strategy of market diversification, export sustainable development

Henan export market is relatively simple, the original main export regions, Henan export enterprises should continue to maintain their superiority on the one hand, on the other hand to further intensify research on international markets, further changes in the characteristics of the target market according to the needs of consumers depth market segmentation, to achieve the traditional export markets in the US, the EU, Hong Kong's sustainable development. For Africa, ASEAN and other export business with less market, Henan export enterprises cannot be ignored, should be based on a combination of factors which local consumer spending, consumption habits, cultural and other input its matching products, and actively strengthen cooperation with foreign brokers, gradually open the market. Like India, Brazil, Russia these countries in the coming years will enter a stage of rapid economic development, domestic consumer demand will continue to expand and upgrade, Henan export enterprises should focus on the development of these national markets, in addition to direct exports, you can also choose to select Contracts entered, foreign direct investment, etc. Such open the door to these fast developing markets.

7). Innovative ideas, accelerate the transformation of foreign trade development mode

For a long time, Henan export growth mainly depends on local resources, a large number of inputs of labor and implementation. Exports are often located in the bottom of the smile curve the industry value chain, the lack of its own intellectual property rights and core technologies. The future development and social progress of mankind is on the technical content of international commodity knowledge content increasingly demanding. If we stick to our own way, see the future development trend of exports, it would only be eliminated by the international market. Eyes, we have to bold innovation, changing the traditional export growth, the extensive growth mode gradually to the products of high technological content, good economic returns, low resources consumption, the new road of growth of the economy less environmental pollution, and promote the export economy in Henan intensive development, innovation and development, harmonious development. Original dominant export commodity trade position gradually developed trade in goods and trade in services to keep pace with a good situation. By the gradual development of the export market single diversified regional markets. From the past emphasis on foreign trade growth rate gradually shift focus on export quality, optimize the structure of export products, and pay attention to the quality of export products. 


\section{Acknowledgments}

This paper is a project of young college teachers sponsorship program of Henan Province.

\section{References}

[1] Jiang Yinyin. Empirical Analysis of relation between export trade and economic growth in Shanghai City. Economist, 2008, (12).

[2] Li Li, Du Ling. Empirical Analysis of relation between export trade and economic growth in China. Finance and trade research, 2007 (4)

[3] Qu Yang, Tang Liang. Empirical Analysis of relation between export trade and economic growth in Jilin Province, Economic Review, 2010（5） 